\title{
Perbaikan Sistem Daya Apung Perahu Fiberglass Guna Meningkatkan Keselamatan Operasi Budidaya Rumput Laut Di Kabupaten Jeneponto
}

\author{
Syamsul Asri ${ }^{*}$, Wahyuddin Mustafa, Farianto Fachruddin, Zulkifli dan Moh.Rizal Firmansyah, \\ Departemen Teknik Perkapalan, Fakultas Teknik Universitas Hasanuddin \\ s.asri@unhas.ac.id*
}

\begin{abstract}
Abstrak
Penduduk Lingkungan Pattontongan Kelurahan Biringkassi Kecamatan Binamu Kabupaten Jeneponto, umumnya merupakan nelayan dan pebudidaya rumput laut. Nelayan dan pebudidaya membentuk komunitas salah satunya adalah kelompok bernama Pattontongan City. Semua anggota kelompok mengelola rumput laut dengan luas lahan perairan sekitar $1 / 2$ hektar per orang. Salah satu sarana transportasi yang digunakan dalam menjalankan aktifitas berupa perahu kecil. Sebagian perahu berbahan kayu dan sebagian berbahan fiberglass. Karakteristik perahu fiberglass antara lain proporsi panjang dan lebarnya besar, proporsi lebar dan tingginya lebih kecil sehingga stabilitasnya kurang baik, oleh karena itu perahu dilengkapi dengan cadik sebagai alat pengatur keseimbangan perahu. Lambung perahu fiberglass dikonstruksi tanpa gading, tebal kulit lambungnya pun relatif tipis. Fitur lainnya yaitu perahu dilengkapi tangki-tangki kosong (void tank) sebagai sistem daya apung. Temuan di lapangan ternyata tangki-tangki ini tidak berfungsi sebagaimana seharusnya, karena tangki-tangki dilubangi dengan diameter sebesar sekitar $10 \mathrm{~mm}$. Kondisi yang demikian itu membuat kapal rentang mengalami risiko ketenggelaman. Solusi yang ditawarkan untuk menjaga proses produksi dan operasi budidaya rumput laut tetap berlangsung adalah memastikan bahwa peluang perahu tenggelam adalah dengan memperbaiki sistem cadangan daya apung bila terjadi kebocoran pada badan perahu. Hasil yang diperoleh melalui perbaikan tangki atau sistem cadangan daya apung ini adalah peserta mampu memahami pentingya sistem cadangan daya apung dalam kaitannya dengan keselamatan jiwa di laut dan mampu menerapkan metode hand lay-up dalam perbaikan sistem cadangan daya apung.
\end{abstract}

Kata Kunci: Perbaikan; Sistem Daya Apung; Tangki; Perahu FRP; Keselamatan Operasi.

\begin{abstract}
The population of Pattontongan area, Biringkassi village, Binamu district, Jeneponto regency are generally working as fishermen and seaweed cultivators. The fishermen and farmers are commonly form a group for their activities. One of the group is called Pattontongan City. Each group member is manage seaweed with an area of $1 / 2$ hectare. They use small boats which are made of wood and fiberglass in carrying out their activities. The characteristics of their boat including the fiberglass boats are; the proportion of the boat length and width is big, while the proportion of the boat width and height is small. Hence the boat stability is not good and must be equipped with outrigger to keep the boat stable. Fiberglass boat hulls are constructed without frames while the thickness of the hull is relatively thin. The boats are also equipped with empty tanks (void tanks) as a buoyancy system. During field visit, it was found that the void tanks as the boat bouyancy system did not work as expected as they apply small $10 \mathrm{~mm}$ diameter of hole in the tanks. The hole will put the boat at the risk of being sinking. The solution offered in order to keep the production process and operation of seaweed farming can still workable is by reducing or omitting the chance of the boat to sink. This can be done by improving the boat buoyancy reserve system. The solution is being introduced and taught to the fishermen and farmers. The results shows that the fishermen and the farmers are understand the importance of the boat bouyancy reserve system and that that the repairing action to the boat void tanks using the hand lay-up method and hence improving the bouyancy reserved system can be easily absorbed by them.
\end{abstract}

Keywords: Repair; Buoyancy System; Tank; FRP Boat; Safety Operation.

\section{Pendahuluan}

Kelompok mitra bernama Pattontongan City merupakan penduduk Lingkungan Pattontongan Kelurahan Biringkassi Kecamatan Binamu Kabupaten Jeneponto. Pekerjaan utama anggota 
kelompok yang berjumlah 25 orang itu adalah nelayan dan pebudidaya rumput laut. Semua anggota kelompok mengelola rumput laut dengan luas lahan perairan sekitar $1 / 2$ hektar per orang.

Salah satu sarana transportasi yang digunakan dalam menjalankan aktifitas berupa perahu kecil. Sebagian perahu berbahan kayu dan sebagian berbahan fiberglass, umumnya perahu fiberglass (FRP-fiberglass reinforced plastic) berasal dari bantuan/hibah pemerintah. Seperti terlihat pada Gambar 1.

Karakteristik perahu fiberglass di daerah pesisir selatan Sulawesi Selatan antara lain proporsi panjang dan lebarnya besar, proporsi lebar dan tingginya lebih kecil sehingga stabilitasnya kurang baik oleh karena itu perahu dilengkapi dengan cadik sebagai alat pengatur keseimbangan perahu. lambung perahu fiberglass dikonstruksi tanpa gading, tebal kulit lambungnya pun relatif tipis (Wahyuddin, 2018).

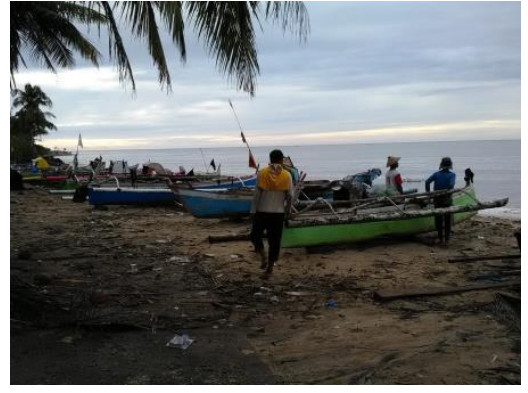

a. Perahu Berbahan Fiberglass Dan Kayu

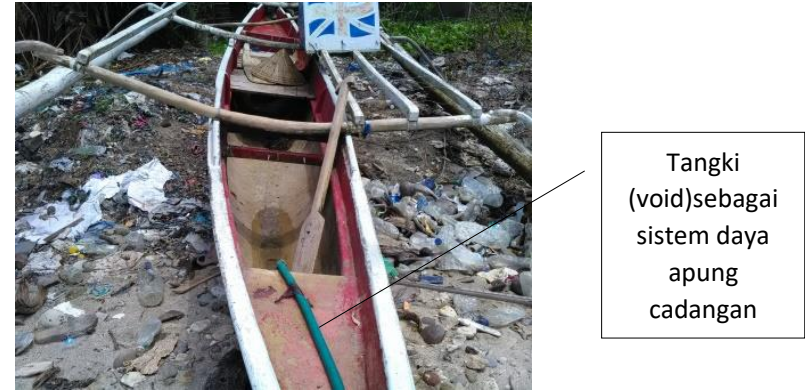

b. Tangki Kosong (Void)

Gambar 1. Sarana Transportasi Nelayan Dan Pebudidaya Rumput Laut Di Lingkungan Pattontongan

Fitur lainnya yaitu perahu dilengkapi tangki-tangki kosong (void tank) sebagai sistem cadangan daya apung yang berfungsi bila perahu mengalami kebocoran. Namun, temuan di lapangan tangki-tangki ini tidak berfungsi sebagaimana desain, oleh karena tangki-tangki dilubangi dengan diameter sekitar $10 \mathrm{~mm}$. Kondisi demikian itu membuat perahu rentang mengalami risiko ketenggelaman. Hal ini berarti bila perahu dipenuhi air langsung tenggelam sampai kedasar laut, tentu hal ini terjadi karena massa jenis perahu sudah melebihi massa jenis air laut atau sistem cadangan daya apung tidak berfungsi.

Apabila perahu tenggelam ke dasar tentu akan menyebabkan proses produksi terhambat dan menyebabkan juga kerugian materil dan kemungkinan jiwa. Solusi yang ditawarkan untuk menjaga proses produksi dan operasi budidaya rumput laut tetap berlangsung adalah memastikan bahwa peluang terjadinya bahaya tenggelam atau risiko perahu tenggelam kecil.

Kepastian ini dapat dicapai melalui pengembangan sistem daya apung cadangan perahu yaitu dengan memastikan bahwa tangki-tangki kosong (void tank) yang ada di perahu berfungsi dengan baik dan atau melengkapi perahu dengan memasang tangki-tangki kosong untuk yang belum ada, memastikan nilai rasio anti ketenggelaman lebih besar dari 1 (satu).

Manfaat program ini adalah untuk membantu menciptakan keselamatan, ketentraman, dan kenyamanan mitra dalam melakukan aktifitas sebagai nelayan dan pebudidaya rumput laut. 


\section{Latar Belakang Teori}

\subsection{Gaya Apung (bouyancy)}

Sebuah benda yang terapung bebas di air akan mengalami gaya ke bawah karena gravitasi. Jika benda memiliki massa $m$, gaya ini akan menjadi mg dan dikenal sebagai beratnya. Jika benda berada dalam keadaan setimbang, harus ada gaya yang sama besarnya dan dalam garis aksi yang sama tetapi berlawanan itulah yang disebut gaya apung. Prinsip ini telah dikemukakan oleh Archimedes seorang filsuf yang tinggal di Syracuse dan Sicily, antara 287 and 212 sebelum masehi, yaitu, "Jika suatu benda dicelupkan ke dalam sesuatu zat cair, benda itu akan mendapat tekanan ke atas yang sama besarnya dengan beratnya zat cair yang terdesak oleh benda tersebut (Tupper, 2013) dan (Biran A.B, 2014).

Berat fluida yang dipindahkan oleh benda terapung secara tepat disebut perpindahan $(\Delta)$, Jika bobot benda apung adalah $\mathrm{W}$, maka dapat diekspresikan kesetimbangan gaya yang bekerja pada benda apung yaitu, (Biran A.B, 2014)

$$
\Delta=W
$$

Prinsip Archimedes menghasilkan persamaan:

$$
\gamma \nabla=W
$$

Jika benda terapung itu adalah sebuah kapal atau perahu, maka persamaan 2 menjadi :

$$
\gamma C b L B T=\sum_{i=l}^{n} W i
$$

dimana $W i$ adalah berat dari sejumlah item berat kapal. Misal, $W_{l}$ dapat menjadi bobot lambung kapal, $W_{2}$ adalah perlengkapan, $W_{3}$ adalah mesin, dan sebagainya. $C b$ adalah koefisien bentuk dan $L$ adalah panjang, $B$ adalah lebar, T adalah sarat kapal atau perahu (Parsons M, 2003) dan (Papanikolaou A, 2014).

\subsection{Cadangan Daya Apung (reserved bouyancy)}

Kapal atau yang terapung bebas di atas permukaan air, biasanya memiliki ruang kedap air (dapat berupa tangki kosong). Bila air masuk ke kapal karena suatu alasan, kapal akan tenggelam lebih rendah di dalam air sampai berat air yang masuk seimbang dengan daya apung tambahan yang dihasilkan oleh volume kedap air. Total daya apung dari volume yang tersedia, itulah yang disebut cadangan daya apung. (Tupper, 2013)

Ratio anti ketenggelaman adalah perbandingan antara volume daya apung dengan berat perahu. bila angka rasio senilai $\geq 1$ bermakna bila perahu kemasukan air memenuhi seluruh lambung, perahu tidak akan tenggelam kedasar dan tetap dalam keadaan mengapung sekalipun posisi terbalik. Besaran volume daya apung cadangan sangat mempengaruhi kapasitas ruang muat, bila volume daya apung cadangan besar maka kapasitas ruang muat mengecil. Dengan kata lain jika rasio anti ketenggelaman $\geq 1$ maka kapasitas ruang muat kecil. (Wahyuddin, 2019)

\subsection{Fiberglass Reinforced Plastic}


Plastik yang diperkuat serat gelas biasa di sebut Fiberglass Reinforced Plastic (FRP). FRP terbentuk dari sejumlah lapisan yang menggabung membentuk komposit yang solid. Apabila syarat-syarat dipenuhi secara seksama dalam proses pembuatan lapisan maka akan menghasilkan sebuah komposit yang kuat dan tahan lama. Sebaliknya jika mengabaikan syarta-syarat maka bahan komposit manjadi rapuh dan cepat rusak (Anmarkrud Thomas, 2009) dan (John McVeagh, et.all, 2010).

Bahan FRP sangat beragam meliputi minyak resin (epoxy resin), katalis (catalis atau hardener), lapisan anti lengket (PVA atau moldrelease), gelcoat (topcoat), serat halus (chopped strand mat atau CSM), lilin (wax), serat kasar (waven roving atau WR, tepung khusus (talc), dempul dan pewarna (pigmen) (Anmarkrud Thomas, 2009).

Alat dan perlengkapan yang digunakan dalam pengerjaan FRP juga sangat beragam meliputi kuas biasa, kuas rol biasa dan besi, gerinda poles dan potong, pisau cutter, gunting, mistar besi, mistar siku, meteran, dan ember.

\subsection{Metode Hand Lay-Up}

Metode yang digunakan untuk pembuatan bangunan baru atau reparasi fiberglass adalah sama yaitu, teknik hand lay-up. Proses teknik hand lay-up untuk kerja reparasi adalah:

1. Periksa kerusakan permukaan seluruh lambung perahu.

2. Tandai yang mengalami kebocoran atau retak atau yang teraberasi.

3. Bersihkan sekitar permukaan yang telah ditandai dengan gerinda.

4. Cuci permukaan lambung yang telah digerinda sampai bersih dari minyak, debu dan lainlain.

5. Campur resin dengan katalis.

6. Sapukan resin dengan kuas ke area yang akan diperbaiki.

7. Potong mat lebih besar dari area yang diperbaiki dan letakkan di sapuan resin sebelumnya.

8. Sapukan resin dan pasang mat yang lebih berat dari sebelumya.

9. Sapukan resin dan pasang roving

10. Jumlah laisan tergantung tebal lambung perahu yang diperbaiki.

11. Terakhir dapat dihaluskan dengan gerinda dan di lapisi dengan cat.

Ilustrasi proses reparasi Teknik hand lay-up dapat dilihat pada Gambar 3. 

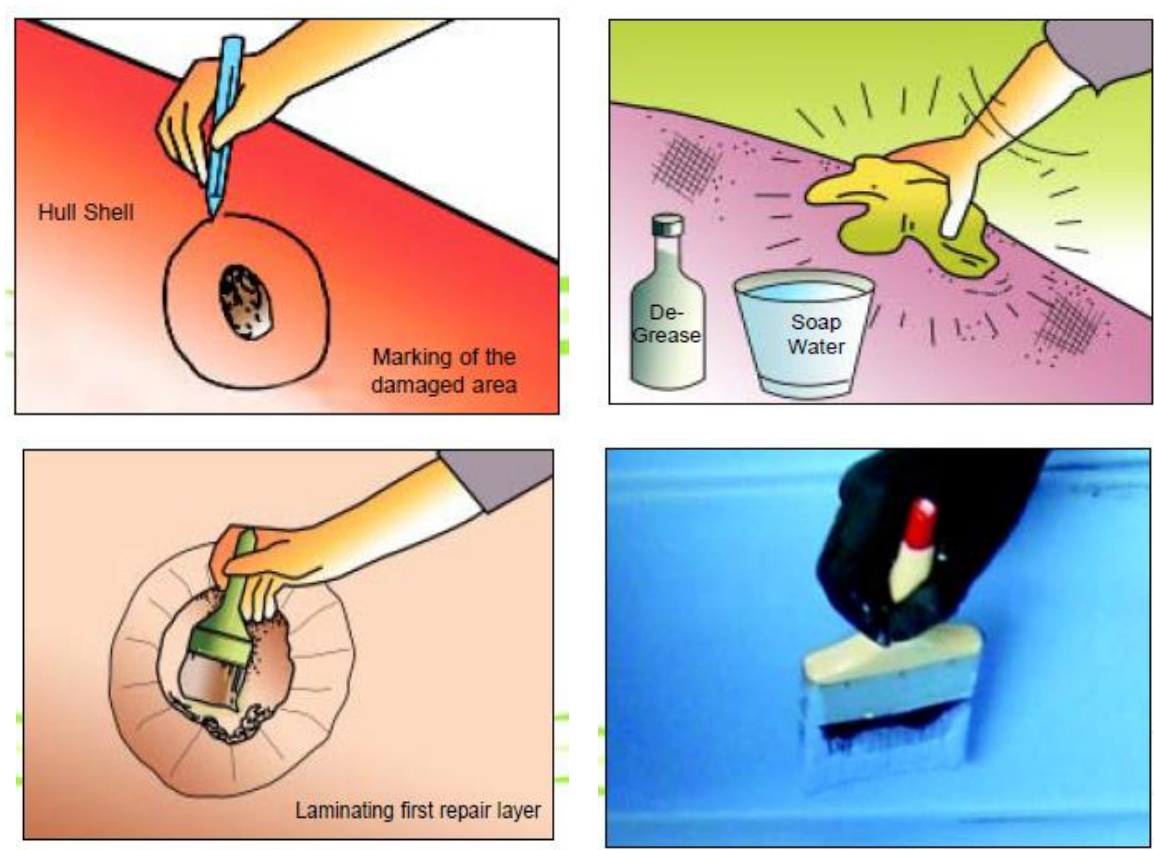

Gambar 2. Proses Teknik Hand Lay-Up Untuk Kerja Reparasi

\subsection{Kesehatan dan Keselamatan Kerja (K3)}

Pekerjaan dengan pembuatan/reparasi perahu fiberglass sangat berisiko dan berbahaya sehingga diperlukan pelindung mata/kaca mata (eye protection), untuk menghidarkan iritasi mata dan kerusakan mata lainnya. Masker (respirator and/or dust mask) guna melindungi diri dari bahaya gas dan debu FRP akibat pengamplasan/pengerindaan. Kaos tangan (gloves) diperlukan untuk melindungi kulit dari bahaya cairan kimia, Perlengkapan K3 seperti terlihat pada Gambar 4.
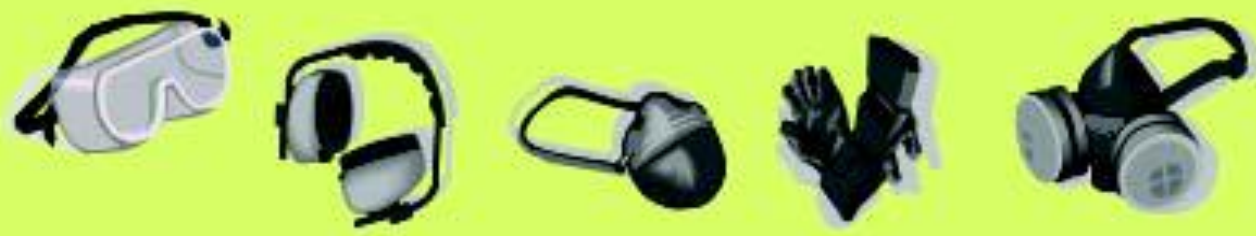

Gambar 3. Perlengkapan K3

\section{Metode}

Solusi yang ditawarkan untuk menjawab permasalahan adalah berupa pelatihan dan bimbingan perbaikan sistem cadangan daya apung dengan tahapan sebagai berikut:

1. Tahap Persiapan, meliputi: penyusunan panduan, penentuan jumlah kebutuhan bahan dan peralatan kerja reparasi fiberglass, dan penyusunan jadwal pelaksanaan kegiatan. 
2. Tahap Pelaksanaan, meliputi:pemberian teori tentang gaya apung dan sistem cadangan daya apung, pemilihan perahu yang akan digunakan sebagai objek kerja dan di uji ketenggelaman, pembersihan perahu, penimbangan perahu, pencampuran bahan fiberglass dan pelapisan bahan fiberglass dan finishing.

3. Tahap Evaluasi, meliputi: pemeriksaaan permukaan lapisan komposit, keretakan dan kebocoran tangki void dan penyampaian hasil analisa sistem cadangan daya apung yaitu desain rencana garis dan rencana umum dan grafik hubungan rasio anti ketenggelaman dengan kapasitas muat perahu objek.

Kegiatan tersebut di atas dilaksanakan di dua tempat yaitu di Labo Produksi Kapal Departemen Teknik Perkapalan FTUH dan Rumah Produksi Perahu Fiberglass Unhas-JICA di Lingkungan Pattontongan Kecamatan Binamu Kabupaten Jeneponto.

\section{Hasil dan Diskusi}

Kelompok mitra "Pattontongan City" sebagian besar anggotanya pernah mendapatkan pelatihan perbaikan lambung fiberglass pada tahun 2016. Keterampilan yang telah diperoleh itu menjadi entry behavior pada program pengabdian ini. Penekanan kegiatan kali ini adalah pemberian pemahaman tentang desain kapal dan keselamatan kapal kaitannya dengan pemasangan tangki kosong (void tank) sebagai sebuah sistem cadangan daya apung.

Visualisasi saat penjelasan tentang sistem cadangan daya apung kaitanya dengan keselamatan jiwa dilaut oleh tim seperti terlihat pada Gambar 5. Selanjutnya, praktek kerja reparasi sistem cadangan daya apung diawali dengan melakukan uji ketenggelaman perahu objek seperti terlihat pada Gambar 6 dan penimbangan perahu dan pembersihan perahu menggunakan gerinda seperti terlihat pada Gambar 7 dan 8.

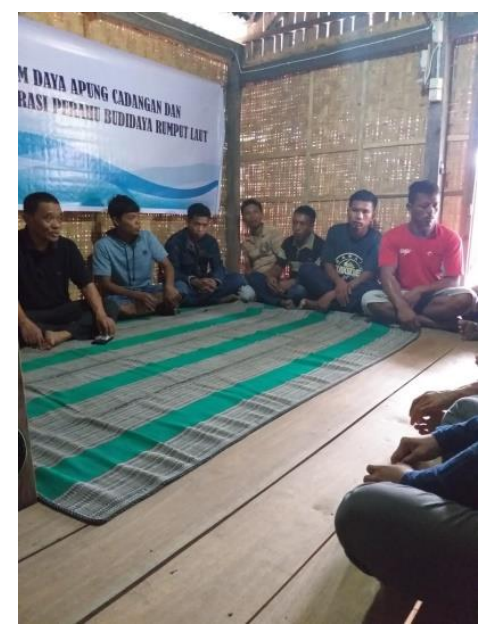

Gambar 4. Peyajian Teori Dan Diskusi Tentang Cadangan Daya Apung
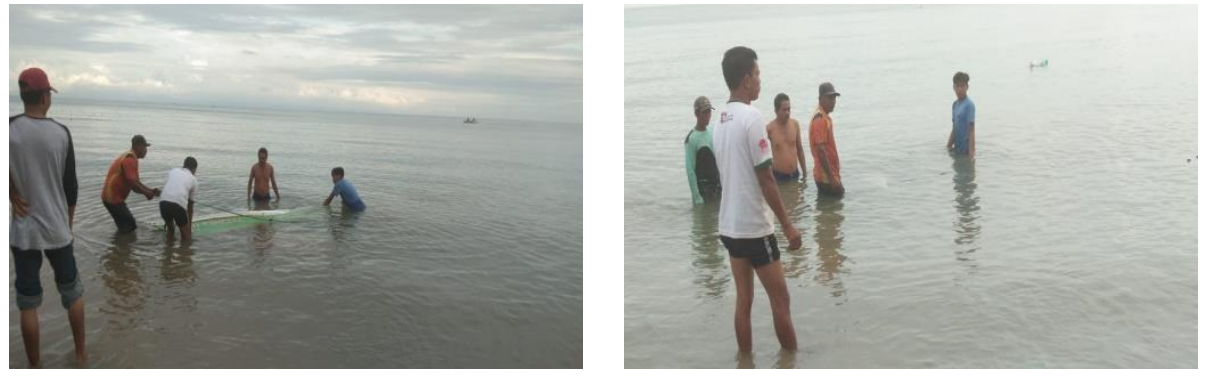
Gambar 5. Uji ketenggelaman perahu fiberglass yang digunakan sebagai sarana budidaya rumput laut di Lingkungan Pattontongan Kabupaten Jenenponto
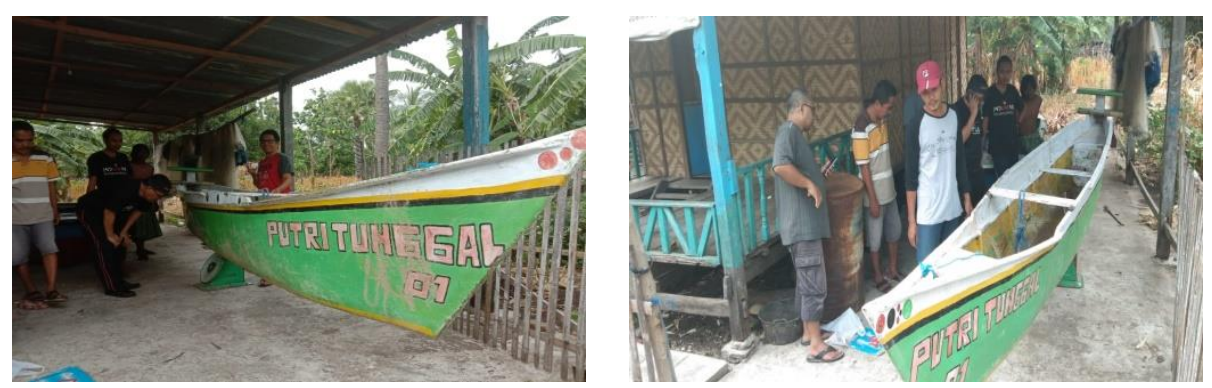

Gambar 6. Penimbangan Perahu
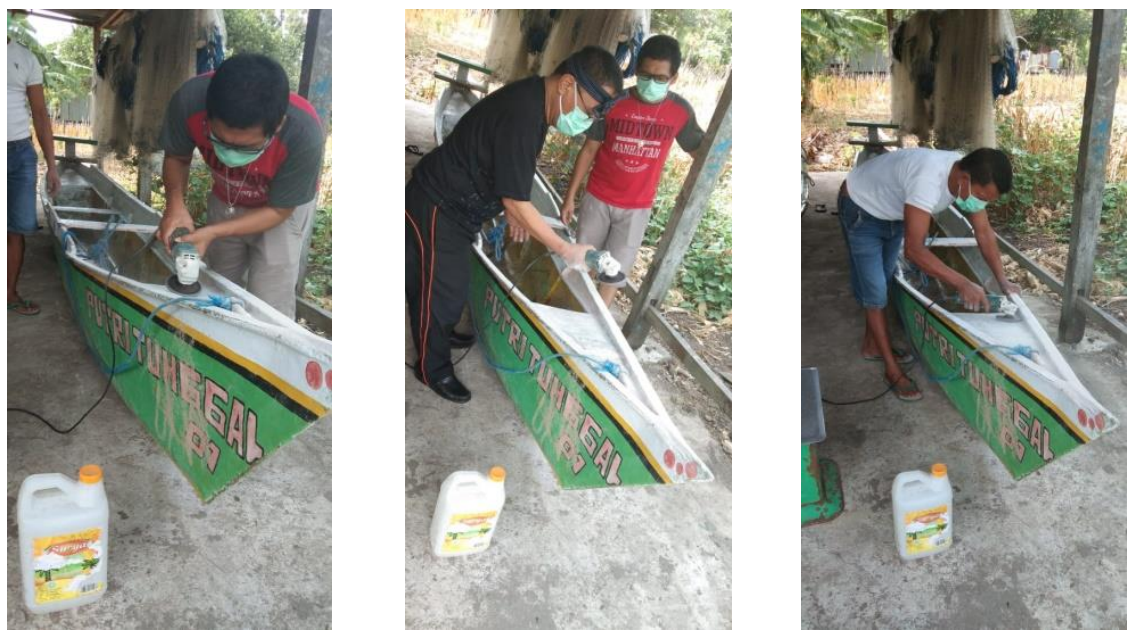

Gambar 7. Pembersihan Tangki Kosong (Void) Perahu

Setelah dibersihkan dari sisa-sisa hasil gerinda dan kotoran lainnya tangki siap untuk dilaminasi. Proses laminasi tangki haluan dan buritan seperti terlihat pada Gambar 9.
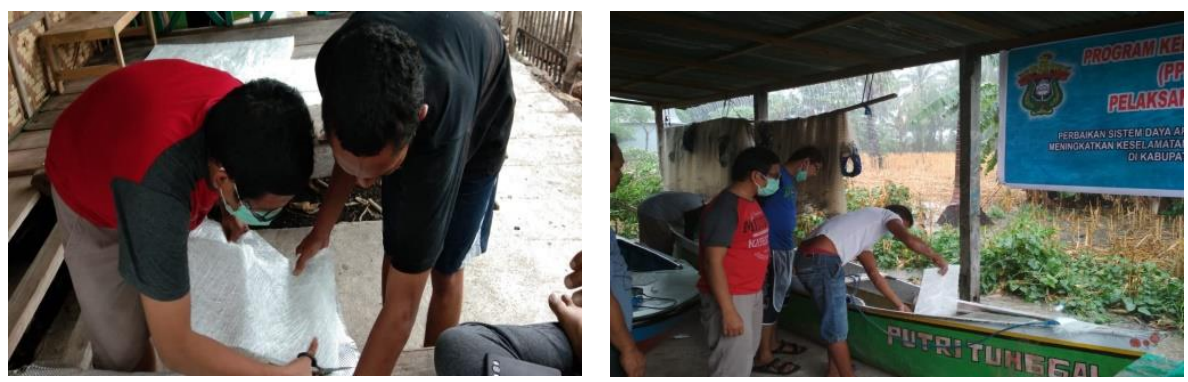

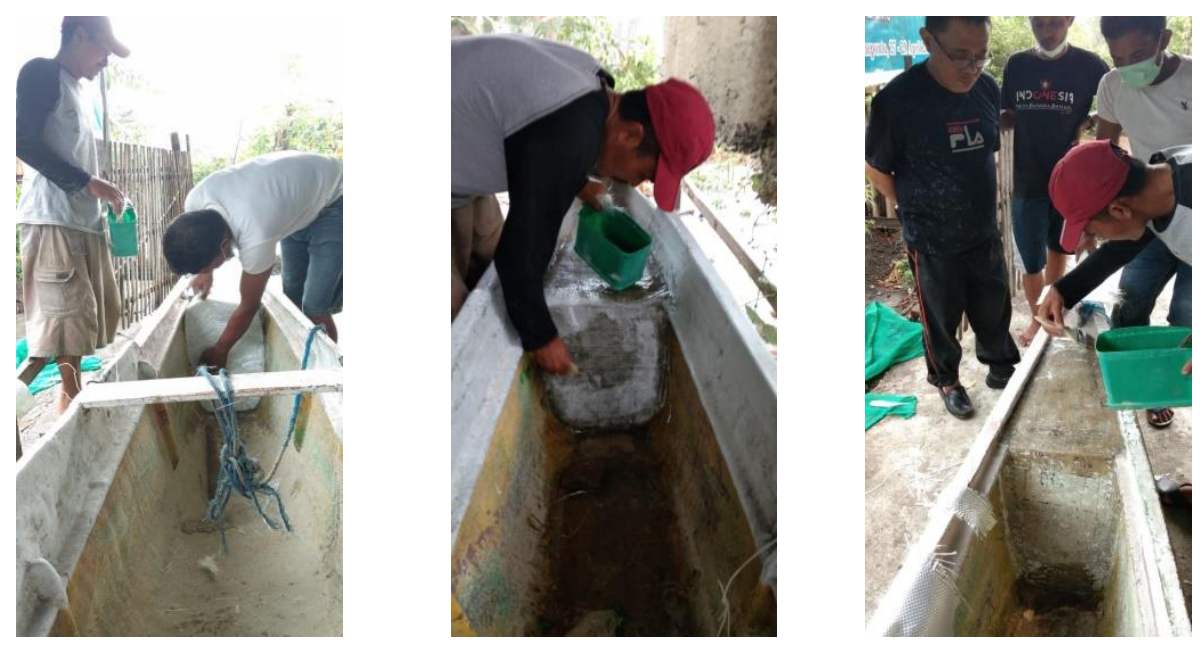

Gambar 8. Proses Laminasi Tangki Cadangan Daya Apung

Proses laminasi metode hand lay-up untuk perbaikan tangki kosong (void tank) adalah sebagai berikut:

1. Campur resin kemudian oleskan secara merata di permukaan cetakan,campuran ini menjadi lapisan pertama komposit.

2. Setelah kering sentuh CSM300 di pasang kemudian diolesi campuran resin secara merata dan tidak ada udara yang terperangkap sehingga CSM300 menyatu sempurna dengan resin.

3. Setelah kering sentuh CSM450 di pasang kemudian diolesi campuran resin secara merata dan tidak ada udara yang terperangkap sehingga CSM450 menyatu sempurna dengan resin.

4. Setelah kering sentuh WR600 di pasang kemudian diolesi campuran resin secara merata dan tidak ada udara yang terperangkap sehingga WR600 menyatu sempurna dengan resin.

5. Setelah kering sentuh CSM450 di pasang kemudian diolesi campuran resin secara merata dan tidak ada udara yang terperangkap sehingga CSM450 menyatu sempurna dengan resin.

6. Setelah kering. permukaan laminasi fiberglass dihaluskan.

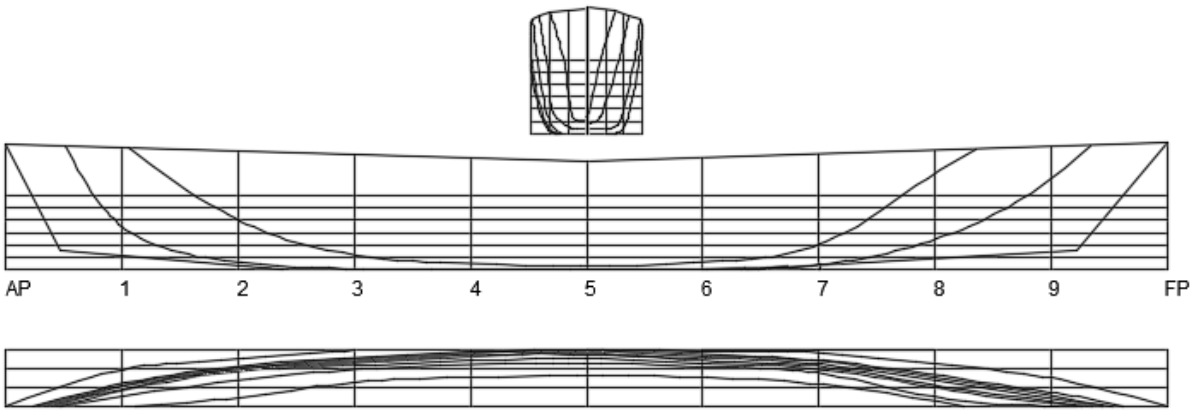

Rencana Garis 


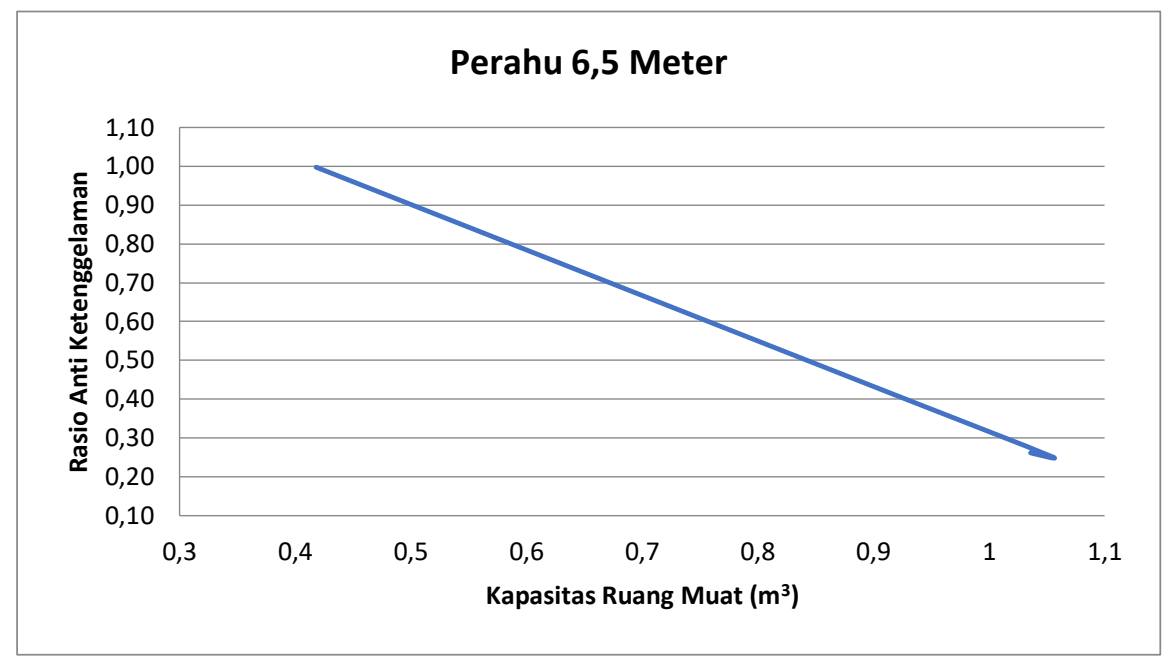

Hubungan rasio anti ketenggelaman dan kapasitas muat perahu.

Gambar 9. Karakteristik Perahu Fiberglass 6,5 Meter

Tahapan selanjutnya adalah melakukan evaluasi terhadap mutu hasil laminasi dengan memeriksa kondisi komposit mencakup keretakan, kebocoran dan tidak adanya udara yang terperangkap dalam lapisan. Evaluasi hasil laminasi dilakukan setelah 5 (lima) bulan sejak proses laminasi. Hasil evaluasi menujukkan kondisi laminasi baik artinya komposit solid.

Evaluasi kedua memperlihatkan hasil desain dan analisa sistem daya apung cadangan. yaitu gambar rencana garis dan hasil analisa berupa grafik hubungan antara rasio anti ketenggelaman dan kapasitas ruang muat, seperti terlihat pada Gambar 10.

Hal yang menjadi topik diskusi pada pelatihan adalah kapasitas sistem cadangan daya apung. Kebanyakan perahu yang dipergunakan pebudidaya kapasitas cadangan daya apung yang sangat rendah sehingga peluang perahu tenggelam masih sangat besar. Karena itu perlu pendekatan untuk mengubah desain perahu saat ini. Kendala yang diperoleh di lapangan, pebudidaya keberatan menambah tangki di tengah kapal karena masalah kemudahan bongkar muat rumput laut. Padahal dengan penambahan tangki kosong ditengah perahu dapat menambah cadangan daya apung dan memperkuat struktur perahu.

\section{Kesimpulan}

Berdasarkan hasil pelatihan dan bimbingan kepada pebudidaya tentang perbaikan sistem cadangan daya apung dapat disimpulkan:

1. Peserta mampu memahami pentingya sistem cadangan daya apung dalam kaitannya dengan keselamatan jiwa di laut.

2. Peserta mampu menerapkan metode hand lay-up dalam perbaikan reparasi perahu.

\section{Ucapan Terima Kasih}

Terimakasih kepada semua pihak yang mendukung terlaksananya kegiatan ini terutama Rektor dan Ketua LP2M Universitas Hasanuddin atas dana hibah pengabdian Unhas dan kelompok pebudidaya "Pattontongan City" di Lingkungan Pattontongan Kecamatan Binamu Kabupaten 
Jeneponto.

\section{Daftar Pustaka}

Anmarkrud Thomas, (2009). Fishing Boat Construction: 4; Building an Undecked Fibreglass Reinforced Plastic Boat, FAO, Rome, Italy.

Anmarkrud Thomas, (2010). Guide to simple repairs of FRP boats in a tropical climate, FAO, Rome, Italy.

Biran Adrian B., López-Pulido Rubén and de Juana Gamo Javier, (2014). Ship Hydrostatics and Stability Second Edition, Butterworth-Heinemann is an imprint of Elsevier, Oxford, UK

McVeagh, J. et al, (2010). Training Manual on The Construction of FRP Beach Landing Boats. FAO, Rome, Italy.

Parsons M, (2003). Parametric Design Ship Design and Contruction Vol. 1-2 chapter 11 pp 146, ed Lamb T, SNAME, Jersey City, NJ.

Papanikolaou Apostolos, (2014). Ship Design Methodologies of Preliminary Design, Springer, London.

Wahyuddin Mustafa dkk, (2018). Pelatihan Perbaikan Perahu Kecil Fiberglass Reinforced Plastic (FRP) Untuk Budidaya Rumput Laut di Kabupaten Bantaeng, JURNAL TEPAT: Teknologi Terapan untuk Pengabdian Masyarakat, Volume 1, Nomor 1, Tahun 2018 ISSN 2654-2781.

Wahyuddin Mustafa, Syamsul Asri, M.Rizal Firmansyah, Farianto Fachruddin dan Gregorius Apelaby, (2019). An Improvement for The Design of The Small Fiberglass Seaweed Farmers Boat to Minimize The Sinkable Risk, Proceedings The $3^{\text {rd }}$ EPI International Conference on Science and Engineering (accepted), Gowa.

Wahyuddin Mustafa, Syamsul Asri, M.Rizal Firmansyah, Farianto Fachruddin dan Gregorius Apelaby, (2019). Laporan Akhir Penelitian; Standar Desain Perahu Kecil Fiberglass sebagai Sarana Produksi Usaha Mikro Budidaya Rumput Laut, Fakultas Teknik Unhas, Gowa. 